\title{
Milk production and enteric methane emissions by dairy cows grazing fertilized perennial ryegrass pasture with or without inclusion of white clover
}

\author{
D. Enriquez-Hidalgo, ${ }^{\star} †$ T. Gilliland,†‡ M. H. Deighton, ${ }^{\star} \S$ M. O’Donovan, ${ }^{\star}$ and D. Hennessy ${ }^{\star 1}$ \\ *Animal \& Grassland Research and Innovation Centre, Teagasc, Moorepark, Fermoy, Co. Cork, Ireland \\ †Queen's University Belfast, Belfast, BT7 1NN, United Kingdom \\ $\ddagger$ Agri-Food and Biosciences Institute, Plant Testing Station, Crossnacreevy, Belfast, BT5 7QJ, United Kingdom \\ §Future Farming Systems Research Division, Department of Environment and Primary Industries, Ellinbank, Victoria 3821, Australia
}

\begin{abstract}
An experiment was undertaken to investigate the effect of white clover inclusion in grass swards (GWc) compared with grass-only (GO) swards receiving high nitrogen fertilization and subjected to frequent and tight grazing on herbage and dairy cow productivity and enteric methane $\left(\mathrm{CH}_{4}\right)$ emissions. Thirty cows were allocated to graze either a GO or GWc sward $(\mathrm{n}=15)$ from April 17 to October 31, 2011. Fresh herbage [16 $\mathrm{kg}$ of dry matter $(\mathrm{DM}) / \mathrm{cow}]$ and $1 \mathrm{~kg}$ of concentrate/ cow were offered daily. Herbage DM intake (DMI) was estimated on 3 occasions (May, July, and September) during which $17 \mathrm{~kg}$ of DM/cow per day was offered (and concentrate supplementation was withdrawn). In September, an additional 5 cows were added to each sward treatment $(\mathrm{n}=20)$ and individual $\mathrm{CH}_{4}$ emissions were estimated using the sulfur hexafluoride $\left(\mathrm{SF}_{6}\right)$ technique. Annual clover proportion $( \pm \mathrm{SE})$ in the GWc swards was $0.20 \pm 0.011$. Swards had similar pregrazing herbage mass $(1,800 \pm 96 \mathrm{~kg}$ of $\mathrm{DM} / \mathrm{ha})$ and herbage production $(13,110 \pm 80 \mathrm{~kg}$ of $\mathrm{DM} / \mathrm{ha})$. The GWc swards tended to have lower DM and NDF contents but greater $\mathrm{CP}$ content than GO swards, but only significant differences were observed in the last part of the grazing season. Cows had similar milk and milk solids yields $(19.4 \pm 0.59$ and $1.49 \pm 0.049 \mathrm{~kg} / \mathrm{d}$, respectively) and similar milk composition. Cows also had similar DMI in the 3 measurement periods (16.0 $\pm 0.70 \mathrm{~kg} \mathrm{DM} /$ cow per d). Similar sward and animal performance was observed during the $\mathrm{CH}_{4}$ estimation period, but GWc swards had $7.4 \%$ less NDF than GO swards. Cows had similar daily and per-unit-of-output $\mathrm{CH}_{4}$ emissions $\left(357.1 \pm 13.6 \mathrm{~g}\right.$ of $\mathrm{CH}_{4} /$ cow per day, 26.3 $\pm 1.14 \mathrm{~g}$ of $\mathrm{CH}_{4} / \mathrm{kg}$ of milk, and $312.3 \pm 11.5 \mathrm{~g}$ of $\mathrm{CH}_{4} /$ $\mathrm{kg}$ of milk solids) but cows grazing GWc swards had $11.9 \%$ lower $\mathrm{CH}_{4}$ emissions per unit of feed intake than cows grazing GO swards due to the numerically lower
\end{abstract}

Received May 16, 2013.

Accepted November 11, 2013.

${ }^{1}$ Corresponding author: deirdre.hennessy@teagasc.ie
$\mathrm{CH}_{4}$ per cow per day and a tendency for the GWc cows to have greater DMI compared with the GO cows. As a conclusion, under the conditions of this study, sward clover content in the GWc swards was not sufficient to improve overall sward herbage production and quality, or dairy cow productivity. Although GWc cows had a tendency to consume more and emitted less $\mathrm{CH}_{4}$ per unit of feed intake than GO cows, no difference was observed in daily or per-unit-of-output $\mathrm{CH}_{4}$ emissions. Key words: $\mathrm{CH}_{4}$ emission, herbage production, milk and milk solids production, white clover

\section{INTRODUCTION}

Temperate dairy grazing systems based on perennial ryegrass (Lolium perenne L.; PRG) swards are highly profitable (Cunningham et al., 1994; Dillon et al., 2005). The productivity of systems based on grass-only (GO) swards relies on high and frequent $\mathrm{N}$ fertilizer application (Frame, 1991; Whitehead, 1995). The European Union Nitrate Directive (Council Directive 91/676/ EEC) limits $\mathrm{N}$ fertilizer use in grassland to $250 \mathrm{~kg}$ of $\mathrm{N} /$ ha per year; therefore, alternative means of increasing $\mathrm{N}$ supply and, therefore, herbage production, warrant investigation. Recent work examining the combination of PRG and white clover (Trifolium repens L., hereafter referred to as clover) has shown promising transgressive overyielding (Kirwan et al., 2009; Gierus et al., 2012). Clover inclusion in PRG swards can increase overall herbage quality due to its high protein and low fiber content (Ulyatt, 1970; Thomson, 1984). Interest in the inclusion of clover in GO swards has been renewed due to clover's ability to fix atmospheric $\mathrm{N}$ and potentially increase the $\mathrm{N}$ supply to the growing sward.

Grazing cattle have a $70 \%$ partial preference for clover compared with PRG when the 2 swards are available simultaneously (Rutter, 2006). Clover fodder has a faster rumen passage rate compared with PRG, as the former is more easily broken down due to its lower fiber content (Beever et al., 1986; Dewhurst et al., 2003). As a result, cows grazing mixed grass and clover swards (GWc) can potentially increase DMI and milk yield 
relative to GO swards (Harris et al., 1997; Phillips and James, 1998; Ribeiro Filho et al., 2003). Those studies reported higher milk yields when cows grazed GWc swards compared with GO swards. Furthermore, previous work has shown that clover preference and DMI is affected by the clover availability and content in GWc swards (Harris et al., 1997; Rutter, 2006).

Agriculture accounts for $13.5 \%$ of the worldwide greenhouse gas (GHG) emissions (IPCC, 2007), and methane $\left(\mathrm{CH}_{4}\right)$ and nitrous oxide are the primary GHG related to the sector. The agricultural sector accounts for $29 \%$ of the worldwide $\mathrm{CH}_{4}$ emissions (UNFCCC, 1997) and in 2010, gas from enteric $\mathrm{CH}_{4}$ fermentation (hereafter referred to as $\mathrm{CH}_{4}$ emissions) accounted for approximately $13.9 \%$ of total Irish GHG emissions (EEA, 2012). In grass-based dairy production systems such as those in Ireland, $\mathrm{CH}_{4}$ emissions account for up to $49 \%$ of the total GHG emissions (Casey and Holden, 2005). Previous studies have reported that net $\mathrm{CH}_{4}$ emissions can be reduced on a per-product basis if animals can be more efficient (Eckard et al., 2010; Buddle et al., 2011; e.g., achieving greater output for the same feed intake). Methane emissions related to gross energy intake of animals fed legumes are lower than animals fed grasses (Waghorn et al., 2006; Beauchemin et al., 2008). However, although some work has shown that clover inclusion in pasture can reduce dairy cow $\mathrm{CH}_{4}$ emissions (Lee et al., 2004) others have found no effects (van Dorland et al., 2007).

Clover contribution to the grazing systems is ultimately related to its content and availability in swards. Nitrogen fertilizer can affect sward clover content through accelerated grass growth and increased grass height, which results in shading of clover and, consequently, a reduction in its growth (Frame and Newbould, 1986; Thompson, 1993; Wilman and Acuña, 1993). Clover content reduction in GWc is usually more severe when high herbage masses are allowed to accumulate (Holmes et al., 1992; Laidlaw et al., 1992; Steen and Laidlaw, 1995). Some studies have suggested that frequent (Harris, 1987; Harris and Clark, 1996; McKenzie et al., 2003b) and tight (Frame and Boyd, 1987; Yu et al., 2008; Phelan et al., 2013) grazing can enhance sward clover content and yield. Sward clover content varies widely throughout the grazing season (Frame and Newbould, 1986; Gilliland et al., 2009) and so it is possible that this variation could affect DMI, $\mathrm{CH}_{4}$ emissions, and ultimately animal production from grazing livestock.

The objective of this experiment was to investigate the effect of clover inclusion in grass swards compared with GO swards receiving high $\mathrm{N}$ fertilization and subjected to frequent and tight grazing on herbage production, $\mathrm{CH}_{4}$ emissions, and dairy cow productivity. It was expected that GWc swards receiving high $\mathrm{N}$ fertilizer input and subjected to frequent and tight grazing would (1) attain sufficient clover content to improve herbage production and quality compared with GO swards and, therefore, (2) increase dairy cow productivity, and (3) reduce $\mathrm{CH}_{4}$ emission.

\section{MATERIALS AND METHODS}

The experiments were undertaken at the Dairygold Research Farm (Teagasc, Animal and Grassland Research and Innovation Centre, Moorepark, Fermoy, Co. Cork, Ireland; $\left.52^{\circ} 09^{\prime} \mathrm{N} ; 8^{\circ} 16^{\prime} \mathrm{W}\right)$. Three 2-ha paddocks were divided (approximately 1 ha each, hereafter referred to as base paddocks) according to a randomized block design and sown with 2 sward treatments of GO and GWc in May 2010. The GO sward was a 50:50 mixture of AstonEnergy (tetraploid) and Tyrella (diploid) PRG cultivars sown at a rate of $37 \mathrm{~kg} / \mathrm{ha}$. The GWc sward contained the same PRG mixture as the GO sward and a 50:50 medium leaf clover mixture of Chieftain and Crusader cultivars sown at a rate of 5 $\mathrm{kg} / \mathrm{ha}$. Swards received $260 \mathrm{~kg}$ of N/ha evenly applied after each grazing rotation between March and mid September as $60 \mathrm{~kg}$ of N/ha of urea $(46 \% \mathrm{~N})$ applied until April and $200 \mathrm{~kg}$ of $\mathrm{N} /$ ha of calcium ammonium nitrate $(27 \% \mathrm{~N})$ thereafter. Swards were grazed once in late February, before the start of the experiment.

\section{Animals and Grazing Management}

In April 2011, 30 spring-calving dairy cows were balanced by breed (Holstein-Friesian, Norwegian Red, and Norwegian Red $\times$ Holstein-Friesian), calving date [February $19(\mathrm{SD}=19.7 \mathrm{~d})]$, lactation number [3.7 (SD $=1.44)]$, milk yield [29.6 $\mathrm{kg}(\mathrm{SD}=3.90)]$, and milk solids (MS) production $[2.2 \mathrm{~kg}(\mathrm{SD}=0.25)]$ using data available for the $3 \mathrm{wk}$ before the start of the experiment. Cows $(\mathrm{n}=30)$ were randomly assigned to 2 herds $(\mathrm{n}=$ 15 ), which rotationally grazed either the GO or GWc sward treatments between April 17 and October 31, 2011. Cows occasionally grazed an identical reserve of GO and GWc paddocks when a shortage of herbage in the base paddocks occurred. Cows received a herbage allowance (HA) of $16 \mathrm{~kg}$ of DM/cow per day $(4 \mathrm{~cm}$ above ground level) and an individual allocation of $1 \mathrm{~kg}$ of concentrate/cow per day $(\mathrm{CP}=154.1, \mathrm{NDF}=40.9$, and ash $=102.8 \mathrm{~g} / \mathrm{kg}$ of DM). Paddocks were strip grazed within rotation, with fresh herbage offered daily following morning milking, after the target postgrazing sward height (PostGSH) of $4 \mathrm{~cm}$ above ground level (hereafter referred to as tight grazing) was attained. Temporary electric fences were used to determine the daily area offered to be grazed, based on the HA and 
the pregrazing herbage mass estimation (see below). Variation in HA was corrected by the PostGSH (i.e., if a PostGSH greater than $4 \mathrm{~cm}$ was measured, cows grazed the same area until the target $4 \mathrm{~cm}$ PostGSH was attained). Cows had ad libitum access to water.

\section{Sward Measurements}

Pre- and Postgrazing Sward Heights and Defoliation Depth. Pregrazing sward height (PreGSH) above ground level was recorded daily in each treatment by taking at least 50 measurements in a $\mathrm{W}$ shape across the strip area about to be grazed using a rising plate meter (Jenquip Ltd., Feilding, New Zealand). Following grazing, a similar procedure was carried out to determine PostGSH above ground level. Defoliation depth was calculated by subtracting PostGSH from the PreGSH.

Sward Clover Content. The GWc sward clover content on a proportion of DM yield basis (hereafter referred to as clover content) was estimated twice per week by removing a composite herbage sample (approximately $70 \mathrm{~g}$ ) above $4 \mathrm{~cm}$ to simulate the target PostGSH, using hand shears (Accu 60; Gardena International GmbH, Ulm, Germany). Herbage samples were selected from at least 10 random locations within the area about to be grazed. Samples were separated into grass and clover fractions, dried at $90^{\circ} \mathrm{C}$ for $15 \mathrm{~h}$, and weighed to determine the sward clover's DM content. Clover production ( $\mathrm{kg}$ of $\mathrm{DM} / \mathrm{ha}$ ) was calculated from the clover content and the respective pregrazing herbage mass.

Herbage Mass and Sward Density. Pregrazing herbage mass $4 \mathrm{~cm}$ above ground level was estimated 2 times per week by harvesting 3 strips of known length (approximately $10 \mathrm{~m}$ ) and width $(1.2 \mathrm{~m}$ ) in the area about to be grazed in each treatment, using a rotary mower (Etesia UK Ltd., Warwick, UK). Harvested herbage was collected, weighed, and subsampled. A subsample of each harvested strip $(0.1 \mathrm{~kg})$ was dried at $90^{\circ} \mathrm{C}$ for $15 \mathrm{~h}$ and weighed to obtain herbage DM content. A composite sample of the 3 harvested strips in each treatment (approximately $0.05 \mathrm{~kg}$ ) was dried at $40^{\circ} \mathrm{C}$ for $48 \mathrm{~h}$, milled through a $2-\mathrm{mm}$ screen, and stored for chemical analysis.

Ten herbage heights were recorded before and after harvesting each strip using the rising plate meter described earlier to determine sward density ( $\mathrm{kg}$ of DM/ $\mathrm{cm}$ per hectare) using the following equation:

$$
\begin{aligned}
& \text { Sward density }(>4 \mathrm{~cm} ; \mathrm{kg} \text { of } \mathrm{DM} / \mathrm{cm} \text { per hectare }) \\
& =\frac{\text { herbage mass }(\mathrm{kg} \text { of } \mathrm{DM} / \mathrm{ha})}{\text { pre-height }- \text { post-height }(\mathrm{cm})} .
\end{aligned}
$$

Total herbage production ( $\mathrm{kg}$ of $\mathrm{DM} / \mathrm{ha}$ ) for each base paddock was calculated as the sum of pregrazing herbage mass in each rotation.

Herbage Chemical Analysis. Samples of the harvested herbage were analyzed by wet chemistry for $\mathrm{OM}$ digestibility (OMD), CP, NDF, ADF, and ash contents. The OMD was estimated using the in vitro neutral detergent cellulase method (Fibertec Systems; Foss Ireland Ltd., Ballymount, Dublin, Ireland) described by Tilley and Terry (1963). Nitrogen content was determined using a N analyzer (FP-428; Leco Australia Pty Ltd., Castle Hill, New South Wales, Australia), based on the Association of Official Analytical Chemists method (AOAC, 1990; method 990-03). Crude protein content was determined by multiplying $\mathrm{N}$ content by 6.25 . The NDF and ADF contents were determined using a fiber analyzer (Ankom Technology, Macedon, NY), based on the method described by Van Soest et al. (1991). Amylase and a sodium sulfite solution were used in the NDF and ADF content determination process. The NDF and ADF values do not include ash values. Ash content was estimated by placing a subsample in a muffle furnace at $500^{\circ} \mathrm{C}$ for $12 \mathrm{~h}$.

\section{Milk Production and Composition, $B C S$, and BW Measurements}

Milking took place at 0730 and $1530 \mathrm{~h}$ daily. Individual cow milk yield ( $\mathrm{kg}$ ) was recorded at each morning and evening milking on a daily basis (Dairymaster, Causeway, Co. Kerry, Ireland). Milk composition (fat, protein, and lactose) was determined weekly via analysis of a representative milk sample collected during successive evening (Monday) and morning (Tuesday) milkings. Milk composition was determined via near infrared spectroscopy using a MilkoScan 203 (DK3400; Foss Electric A/S, Hillerød, Denmark). Milk solids yield $(\mathrm{kg})$ was calculated as the yield of milk fat plus the yield of milk protein.

Body condition score was estimated by an experienced independent observer using a 0 to 5 scale $(0=$ emaciated and $5=$ extremely fat; Lowman et al., 1976) at the beginning and at the end of the experiment. Body weight was recorded on 5 occasions during the experiment (in wk 1, 6, 15, 18, and 22) following morning milking, using a portable weighing scale and the Winweigh software package (Tru-test Ltd., Auckland, New Zealand). The change in BCS and BW was calculated as the difference between the first (wk 1) and the last measurements (wk 22).

\section{Herbage DMI Measurement}

Individual herbage DMI $(\mathrm{n}=30)$ was estimated during three 1-wk periods in May, July, and September 
using the $n$-alkane technique (Mayes et al., 1986), as modified by Dillon (1993). Intake estimation was carried out on the base paddocks only. Three days before the sample collection phase, the concentrate supply was withdrawn and cows received an $\mathrm{HA}$ of $17 \mathrm{~kg}$ of $\mathrm{DM} /$ cow per day. Cows were dosed twice daily for 12 consecutive days after each milking with paper pellets (Carl Roth GmbH, Karlsruhe, Germany) containing $375 \mathrm{mg}$ of dotriacontane $\left(\mathrm{C}_{32}\right.$ alkane). From d 7 to 12 of the dosing period, a fecal sample was collected from each cow twice daily before morning and evening milking, either in the paddock during the hour before milking by observing the cows and collecting the sample when voided, or by rectal grab sampling after milking. Fecal samples were stored at $-17^{\circ} \mathrm{C}$ until the end of the collection period. Fecal samples from each cow were thawed and bulked together $(12 \mathrm{~g}$ from each sample), dried at $60^{\circ} \mathrm{C}$ for $48 \mathrm{~h}$, milled through a 1-mm screen, and analyzed for alkane content. Two herbage samples of approximately 10 individual herbage snips were manually collected daily with the hand shears described earlier to mimic the grazing defoliation pattern observed on previously grazed swards. The samples of herbage offered were stored at $-17^{\circ} \mathrm{C}$. The frozen herbage samples were bowl-chopped (Type MKT 204 Special; Müller, Saarbrücken, Germany), freeze-dried, milled through a 1-mm screen, and analyzed for alkane content. The herbage DMI was estimated using the following equation (Mayes et al., 1986):

$$
\operatorname{DMI}(\mathrm{kg} \text { of DM} / \mathrm{d})=\frac{\left(F_{i} / F_{j}\right) \times D_{j}}{H_{i}-\left[\left(F_{i} / F_{j}\right) \times H_{j}\right]},
$$

where $H$ is the alkane concentration of the herbage $(\mathrm{mg} / \mathrm{kg}$ of DM), $F$ is the alkane concentration of feces $(\mathrm{mg} / \mathrm{kg}$ of $\mathrm{DM}), i$ is the natural or internal marker alkane with odd number of carbon atoms $\left(\mathrm{C}_{33}\right), j$ is the synthetic or external marker alkane with even number of carbon atoms $\left(\mathrm{C}_{32}\right)$, and $D j$ is the daily dose $\mathrm{C}_{32}$ (mg/d) alkane.

\section{Enteric Methane Emissions Estimations}

During the September DMI estimation period, an additional 10 cows (balanced for the same traits used for the main herds) were randomly assigned to each of the 2 herds $(n=20)$ to improve the power of the estimations. Dry matter intake was also estimated on these cows as described above. Individual $\mathrm{CH}_{4}$ emissions for all cows $(\mathrm{n}=40)$ were determined using the calibrated sulfur hexafluoride $\left(\mathrm{SF}_{6}\right)$ tracer gas technique developed by Zimmerman (1993), with modifications for grazing dairy cattle (Deighton et al., 2013). Permeation tubes containing approximately $2.5 \mathrm{~g}$ of $\mathrm{SF}_{6}$ were manufactured following the method of Deighton et al. (2013), balanced by permeation rate $[10.0 \mathrm{mg} / \mathrm{d}(\mathrm{SD}=1.38)]$ and randomly assigned to the cows within each treatment group. Each cow was orally dosed using a single permeation tube $9 \mathrm{~d}$ before collection of gas samples commenced.

Each cow was fitted with a padded canvas saddle and a head collar $3 \mathrm{~d}$ before the sample collection period. The saddles, described by Deighton et al. (2013), enabled a single 2.14-L gas collection canister to be fitted to the back of each cow. Canisters with an initial vacuum of $90 \mathrm{kPa}$ below atmospheric pressure drew air from a point near each cows nostrils to collect a representative sample of expired and eructated gases. An identical canister was placed beside each grazed area to collect atmospheric $\mathrm{CH}_{4}$ and $\mathrm{SF}_{6}$. The rate of gas collection was determined to be approximately $0.6 \mathrm{~mL} / \mathrm{min}$ using a digital flow meter (Cole-Parmer Instrument Co., Vernon Hills, IL). Gas samples were collected continuously for $6 \mathrm{~d}$ (September 11 to 16) by replacing canisters after morning milking each day. Concentrations of $\mathrm{SF}_{6}$ and $\mathrm{CH}_{4}$ within collected samples were determined using gas chromatography as described by Johnson et al. (2007), using a Varian 3800 gas chromatograph (Varian Inc., Palo Alto, CA). Daily $\mathrm{CH}_{4}$ emissions of each cow were calculated using Equation 2 of Williams et al. (2011). Daily milk production, weekly milk components analysis, MS production, BW, and DMI data collected for each cow during the period of gas sample collection were correlated with $\mathrm{CH}_{4}$ emissions.

\section{Statistical Analysis}

Statistical analyses were carried out using repeated measures with PROC MIXED of SAS 9.1.3 software (SAS Institute, 2003). Data are presented as least squares means \pm standard error. Interactions and the covariates were checked independently for every variable and were removed from the model if they had a $P$-value $>0.3$.

Herbage data were analyzed, including the sward type, the rotation, and sward type and rotation interaction in the model, with paddock as the experimental unit, block as a random factor, and the rotation as a repeated measure.

Animal measurements were analyzed using individual cows as the experimental unit. Although previous work has found that cows show synchronized grazing behavior activities within the herd (Rook and Huckle, 1995), no evidence exists that the production of isolated animals and groups are different. Additionally, the synchronization of grazing behavior does not imply that the behavior of individual cows is interdependent, 
Table 1. Main climatic data during the experimental period (April 17 to October 31, 2011) compared with the previous 10-yr average

\begin{tabular}{|c|c|c|c|c|c|c|c|c|}
\hline Item & Year & \multicolumn{7}{|c|}{ Month } \\
\hline Total rainfall, mm & 2011 & 26 & 81 & 62 & 55 & 35 & 99 & 83 \\
\hline \multirow[t]{2}{*}{ Mean daily air temperature, ${ }^{\circ} \mathrm{C}$} & 2011 & 10.7 & 11.4 & 12.2 & 14.1 & 13.2 & 13.5 & 11.5 \\
\hline & 2001 to 2010 & 8.9 & 11.4 & 14.2 & 15.5 & 15.4 & 13.6 & 10.7 \\
\hline
\end{tabular}

as their behavior may be affected by external factors that influence all animals equally (i.e., environmental and husbandry influences; Phillips, 1998). Days in milk at the beginning of the experiment, the 3 -wk preexperimental average data for milk yield and milk composition, and preexperimental BW data were included as covariates. These variables were analyzed using the following model:

$$
\begin{gathered}
Y_{i j k l}=\mu+C_{i}\left(S_{k}\right)+P_{j}+S_{k}+w k_{l}+P_{j} \times S_{k} \\
\quad+w k_{l} \times S_{k}+b_{1} X_{i j k}+b_{2} \operatorname{DIM}_{i j k}+e_{i j k l},
\end{gathered}
$$

where $Y_{i j k l}$ is the response of the $i$ th cow in the $k$ th sward at the lth week, $\mu$ is the mean, $C_{i}\left(S_{k}\right)$ the random effect of the cow within sward type, $P_{j}$ is the parity ( $j$ $=2$ to 6$), S_{k}$ is the sward type $\left(k=\mathrm{GO}\right.$ or GWC), $w k_{l}$ is the week of the experiment ( 1 to 28$), P_{j} \times S_{k}$ is the interaction of $P_{j}$ and $S_{k}, w k_{l} \times S_{k}$ is the interaction of $w k_{l}$ and $S_{k}, b_{1} X_{i j k}$ is the respective preexperimental variable, $b_{2} \mathrm{DIM}_{i j k}$ is the DIM at the start of the experiment, and $e_{i j k l}$ is the residual error term. Week was used as the repeated measure. Herbage DMI estimations were analyzed using a similar model to that described above, with the estimation period (May, July, or September) as the repeated measure.

Methane emissions were averaged to obtain a single value per cow $(\mathrm{n}=40)$ and data were analyzed as 20 individual measurements per treatment. Overall, the anticipated collection of 240 individual gas samples was $79 \%$ successful. Samples were lost due to sampling tube blockages, broken collection tubes, and occasional dismounting of saddles during the 6-d sampling period. This resulted in the exclusion of 2 GWc cows and 1 GO cow from the analysis, as less than 3 usable samples were available for these animals. Animal-related variables during the $\mathrm{CH}_{4}$ estimation period were analyzed, including treatment, parity, and the treatment $\times$ parity interaction as fixed effects; DIM as a covariate; and cow nested within treatment as random effect.

\section{RESULTS}

The main climatic data during the experimental period is presented in Table 1 . Total rainfall was $22 \%$ lower than the average observed during the previous 10 yr (442 and $567 \mathrm{~mm}$, respectively) and 33\% lower in the January to March period before the start of the experiment. Mean daily temperature during the months of the experiment were similar to the 10 -yr average, excluding April when the temperatures were $20 \%$ higher than the 10-yr average.

\section{Sward Measurements}

The effect of sward type on sward measurements and herbage chemical composition is shown in Table 2. An effect was observed of rotation $(P<0.05)$ on all sward measurements and chemical composition fractions. The sward type and rotation interaction $(P<$ $0.05)$ influenced pregrazing herbage mass. Pregrazing herbage mass was higher $(P<0.05)$ for GO swards in the third rotation, and in the fifth and seventh, it was numerically lower than for GWc swards. No effect $(P$ $>0.1$ ) was observed of sward type on the rest of the sward measurements undertaken (Table 2). Total herbage production from the base paddocks was also similar for both treatments $(13,110 \pm 80 \mathrm{~kg}$ of DM/ha). Grass clover swards tended $(P=0.1)$ to have a lower DM proportion and lower NDF $(P<0.06)$ and greater $\mathrm{CP}$ contents $(P=0.1)$ than GO swards.

The average GWc sward clover content was $0.20 \pm$ 0.023. Clover DM production in the GWc swards averaged $340 \pm 30 \mathrm{~kg}$ of DM/ha (Figure 1) in each grazing rotation. An effect was observed of rotation $(P<0.05$; Figure 1) on both variables as, in general terms, sward clover content and clover production increased as the experiment progressed. The greatest sward clover content was observed in the eighth rotation, in October $(0.26 \pm 0.022)$, and the greatest clover DM yield was measured in the seventh rotation, in September (546 \pm $53.92 \mathrm{~kg}$ of DM/ha).

\section{Milk Production and Composition, BCS, and BW}

The effect of sward type on milk yield, milk composition, BW, and BCS of spring-calving dairy cows during the experimental period (April 17 to October 31, 2011) is shown in Table 3 . No effect $(P>0.05)$ was observed 
Table 2. Effect of sward type on sward measurements and herbage chemical composition during the total experimental period (LSM; April 17 to October 31, 2011)

\begin{tabular}{|c|c|c|c|c|c|c|c|c|c|c|}
\hline \multirow[b]{2}{*}{ Item } & \multirow[b]{2}{*}{ Sward $^{1}$} & \multicolumn{8}{|c|}{ Rotation/month } & \multirow[b]{2}{*}{ Mean } \\
\hline & & 1/April & 2/May & 3/June & 4/June & 5/July & 6/August & 7/September & 8/October & \\
\hline \multirow[t]{3}{*}{ Pregrazing sward height, $\mathrm{cm}$} & GO & 11.3 & 10.4 & 10.9 & 11.1 & 7.9 & 7.3 & 10.3 & 9.3 & 9.8 \\
\hline & GWc & 11.1 & 10.7 & 10.4 & 10.9 & 9.0 & 7.9 & 11.1 & 9.6 & 10.1 \\
\hline & SED & 0.68 & 0.64 & 0.63 & 0.69 & $0.63 \dagger$ & 0.55 & 0.57 & 0.62 & 0.39 \\
\hline \multirow[t]{3}{*}{ Postgrazing sward height, $\mathrm{cm}$} & GO & 3.9 & 4.0 & 4.3 & 4.6 & 4.3 & 4.3 & 4.2 & 4.1 & 4.2 \\
\hline & GWc & 4.1 & 4.0 & 4.2 & 4.3 & 4.1 & 4.2 & 4.0 & 3.9 & 4.1 \\
\hline & SED & 0.21 & 0.20 & 0.20 & 0.22 & 0.20 & 0.18 & 0.18 & 0.20 & 0.14 \\
\hline \multirow[t]{3}{*}{ Defoliation depth, cm } & GO & 7.4 & 6.4 & 6.6 & 6.9 & 3.6 & 3.0 & 6.0 & 5.3 & 5.7 \\
\hline & GWc & 7.0 & 6.7 & 6.2 & 6.4 & 4.8 & 3.7 & 7.0 & 5.5 & 5.9 \\
\hline & SED & 0.66 & 0.60 & 0.60 & 0.70 & $0.60^{*}$ & 0.53 & $0.51 \dagger$ & 0.59 & 0.34 \\
\hline \multirow[t]{3}{*}{ Pregrazing herbage mass $(>4 \mathrm{~cm}), \mathrm{kg}$ of DM/ha } & GO & 1,770 & 1,600 & 2,040 & 2,360 & 1,560 & 1,440 & 2,090 & 1,600 & 1,810 \\
\hline & GWc & 1,660 & 1,630 & 1,720 & 2,190 & 1,780 & 1,480 & 2,240 & 1,580 & 1,780 \\
\hline & SED & 153 & 144 & $143^{*}$ & 151 & 144 & 122 & 128 & 133 & 96 \\
\hline \multirow[t]{3}{*}{ Sward density $(>4 \mathrm{~cm}), \mathrm{kg}$ of $\mathrm{DM} / \mathrm{cm}$ per hectare } & GO & 239 & 225 & 277 & 340 & 433 & 340 & 292 & 190 & 292 \\
\hline & GWc & 236 & 221 & 257 & 365 & 368 & 287 & 267 & 196 & 275 \\
\hline & SED & 35.3 & 32.1 & 29.7 & 34.2 & $33.5 \dagger$ & 35.9 & 30.4 & 34.7 & 15.1 \\
\hline \multicolumn{11}{|l|}{ Chemical composition (herbage $>4 \mathrm{~cm}$ ) } \\
\hline \multirow[t]{3}{*}{$\mathrm{DM}, \mathrm{g} / \mathrm{kg}$ of $\mathrm{DM}$} & GO & 171 & 154 & 182 & 181 & 193 & 201 & 166 & 132 & 173 \\
\hline & GWc & 170 & 148 & 183 & 189 & 174 & 169 & 149 & 123 & 163 \\
\hline & SED & 13.0 & 11.8 & 10.9 & 12.5 & 12.4 & $13.3^{*}$ & 11.4 & 12.4 & $5.1 \dagger$ \\
\hline \multirow{3}{*}{$\mathrm{OMD},{ }^{2} \mathrm{~g} / \mathrm{kg}$ of $\mathrm{DM}$} & GO & 766 & 777 & 812 & 795 & 772 & 769 & 769 & 772 & 779 \\
\hline & GWc & 753 & 794 & 815 & 785 & 776 & 782 & 785 & 789 & 785 \\
\hline & SED & 15.0 & 13.0 & 13.0 & 15.0 & 12.3 & 13.4 & 12.3 & 12.3 & 4.9 \\
\hline \multirow[t]{3}{*}{$\mathrm{CP}, \mathrm{g} / \mathrm{kg}$ of $\mathrm{DM}$} & GO & 202 & 240 & 197 & 182 & 199 & 203 & 220 & 246 & 211 \\
\hline & GWc & 201 & 235 & 198 & 186 & 206 & 231 & 236 & 269 & 220 \\
\hline & SED & 11.9 & 10.8 & 10.0 & 12.7 & 11.6 & $12.1^{*}$ & 10.5 & $11.3^{*}$ & $5.2 \dagger$ \\
\hline \multirow{3}{*}{$\mathrm{ADF}, \mathrm{g} / \mathrm{kg}$ of $\mathrm{DM}$} & GO & 247 & 291 & 251 & 259 & 306 & 290 & 282 & 311 & 280 \\
\hline & GWc & 247 & 280 & 254 & 272 & 304 & 313 & 279 & 313 & 283 \\
\hline & SED & 13.5 & 12.3 & 11.3 & 14.5 & 13.4 & $13.9 \dagger$ & 11.9 & 13.0 & 5.2 \\
\hline \multirow[t]{3}{*}{$\mathrm{NDF}, \mathrm{g} / \mathrm{kg}$ of DM } & GO & 403 & 429 & 391 & 404 & 436 & 416 & 428 & 449 & 419 \\
\hline & GWc & 400 & 414 & 382 & 417 & 419 & 392 & 401 & 422 & 406 \\
\hline & SED & 13.0 & 11.8 & 11.0 & 14.6 & 12.8 & $13.3 \dagger$ & $11.5^{*}$ & $12.5^{*}$ & $5.6 \dagger$ \\
\hline \multirow{3}{*}{ Ash, $\mathrm{g} / \mathrm{kg}$ of $\mathrm{DM}$} & GO & 126 & 146 & 124 & 137 & 143 & 157 & 116 & 138 & 136 \\
\hline & GWc & 130 & 139 & 133 & 143 & 151 & 139 & 117 & 156 & 139 \\
\hline & SED & 12.3 & 11.1 & 10.5 & 13.1 & 12.9 & 14.0 & 10.8 & 11.7 & 5.1 \\
\hline
\end{tabular}

${ }^{1} \mathrm{GO}=$ grass-only sward; GWc $=$ grass + white clover sward; $\mathrm{SED}=\mathrm{SE}$ of the difference between sward type within rotation

${ }^{2} \mathrm{OMD}=\mathrm{OM}$ digestibility.

ऽ $\dagger P<0.10 ; * P<0.05$. 
Table 3. Effect of sward type on milk production, milk composition, and animal performance of spring-calving dairy cows ( $\mathrm{n}=30$ ) during the total experimental period (LSM; April 17 to October 31, 2011)

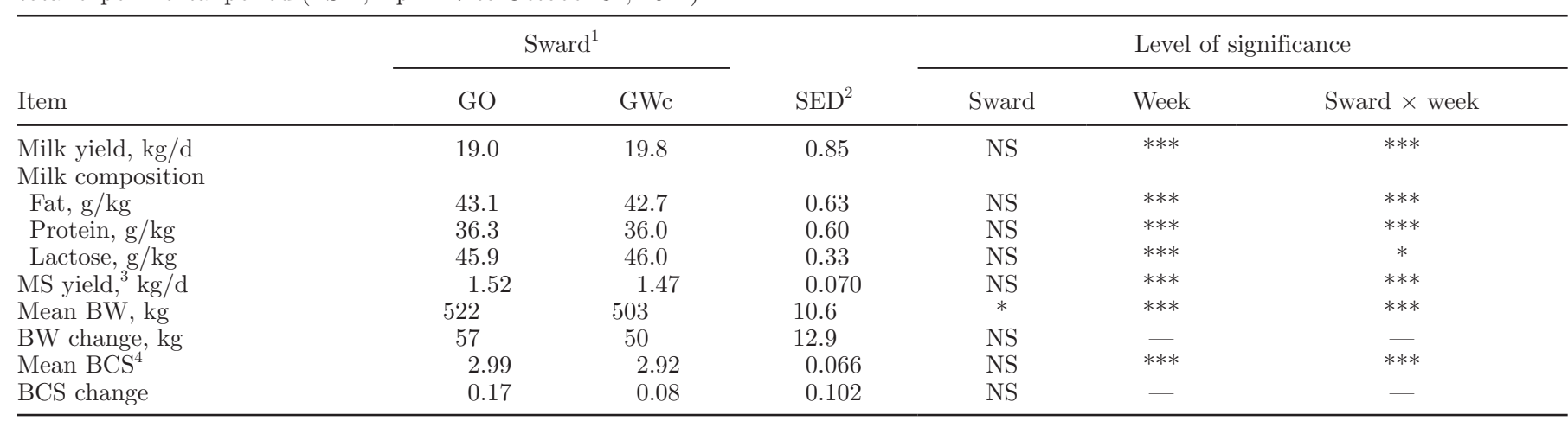

${ }^{1} \mathrm{GO}=$ grass-only sward; GWc $=$ grass + white clover sward.

${ }^{2}$ Standard error of the difference.

${ }^{3} \mathrm{MS}=$ milk solids.

${ }^{4}$ Body condition score was on a scale of 1 to 5 ( $1=$ emaciated and $5=$ extremely fat, using 0.25 increments).

${ }^{*} P<0.05$; *** $P<0.001$.

of sward type on milk and MS yields or the milk composition variables measured, the cumulative milk yield $(3,804 \pm 124.11 \mathrm{~kg} / \mathrm{cow})$, or the cumulative MS yield $(292.5 \pm 9.64 \mathrm{~kg} / \mathrm{cow})$. Daily milk yield and daily MS yield decreased as the experiment progressed (Figure $2)$. The sward type $\times$ time interaction influenced $(P<$ 0.001) all milk variables. Across measurement weeks, milk yield was similar for both treatments until wk 17 of the experiment and afterward it was slightly higher for GWc cows than for GO cows (Figure 2). Milk solids yield was slightly higher for GO cows than GWc cows in wk 9, 10, and 16 (Figure 2). Milk fat content was higher for the GO treatment than for the GWc treatment between wk 8 and $11(P<0.05)$ of the experiment, but no other clear trends were observed apart from this period.

Cows grazing GWc swards were, on average, $19 \mathrm{~kg}$ lighter $(P<0.05)$ than cows grazing GO swards during

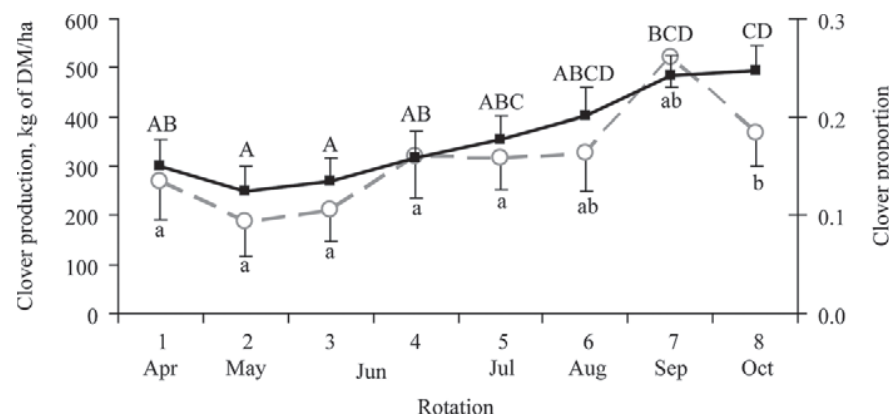

Figure 1. Least squares means of clover production (--○--) and clover proportion $(--)$ in the pregrazing herbage mass $(>4 \mathrm{~cm})$ of the grass + white clover swards during the experimental period (April 17 to 31 October 31, 2011). Error bars represent SE. Rotations with different lowercase (a and b; clover production) and uppercase (A-D; clover proportion) letters differ $(P<0.05)$ among rotations. the experiment (Table 3); however, no effect of sward type on BW change was observed between the 2 groups of cows. No differences in mean BCS or BCS change were observed between cows on the different sward types. No significant difference was observed in DMI between sward treatments within the intake estimation period (May: $16.1 \pm 0.70 \mathrm{~kg}$ of DM/cow per day; July: $15.7 \pm 0.70 \mathrm{~kg}$ of $\mathrm{DM} /$ cow per day; September $16.3 \pm$ $0.70 \mathrm{~kg}$ of $\mathrm{DM} /$ cow per day).

\section{Enteric Methane Emissions}

The effect of sward type on sward measurements and herbage chemical composition, animal measurements, and $\mathrm{CH}_{4}$ emissions during the week of the $\mathrm{CH}_{4}$ emissions estimation is shown in Table 4. The GWc swards had $7.4 \%$ lower NDF than GO swards $(P<0.01)$; no significant differences existed between treatments for any of the other sward measurements. During the week of the $\mathrm{CH}_{4}$ emissions estimation period, the clover content of the GWc sward was $0.24 \pm 0.031$. Cows grazing GWc swards had $7.8 \%$ greater $(P<0.05)$ milk fat content and $11.9 \%$ less $(P<0.05) \mathrm{g}$ of $\mathrm{CH}_{4} / \mathrm{kg}$ of DMI than cows grazing GO swards. The GWc cows also tended ( $P$ $=0.07)$ to have greater DMI than the GO cows.

\section{DISCUSSION}

\section{Sward Measurements}

Within this experiment, the annual average clover content of the GWc swards was relatively low (0.20), especially during the first 4 rotations (average 0.15 ). Greater rates of spring growth and response to $\mathrm{N}$ fertilizer application favor the competitive ability of grass 
a)
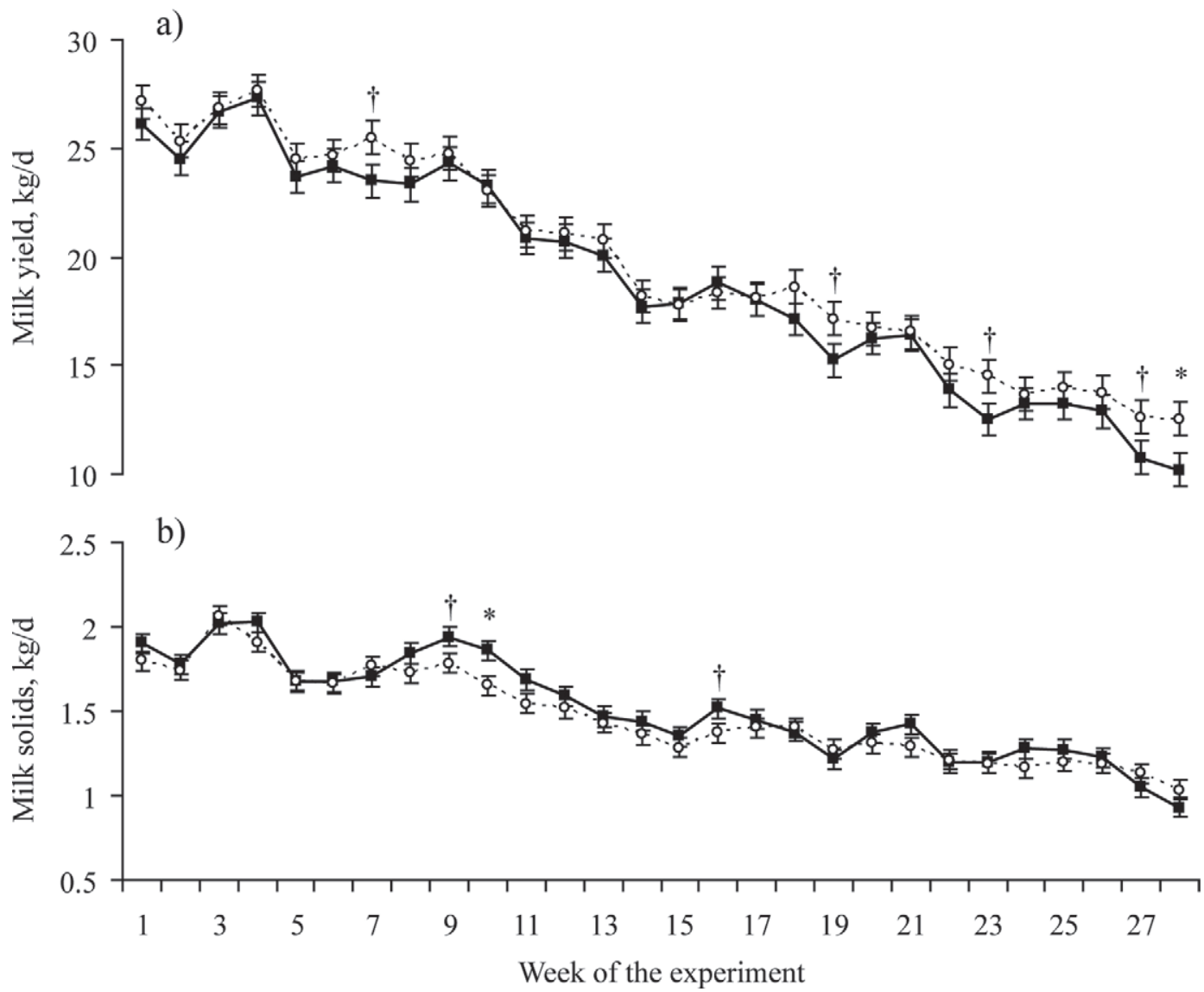

Figure 2. Least squares means of the effect of sward type [grass only $(-\mathbf{-}-)$; grass + white clover $\left(---_{--}\right)$] on dairy cow $(\mathrm{n}=30)$ daily milk yield (a) and milk solids (b) across the experimental period (April 17 to October 31, 2011). Error bars represent SE. $\dagger P<0.10 ; * P<0.05$.

over clover within GWc swards (Frame and Newbould, 1986; Ledgard et al., 1995; Andrews et al., 2007). Frequent harvesting of the additional grass growth resulting from the fertilizer $\mathrm{N}$ minimizes shading and, to some extent, suppresses grass growth to the benefit of clover (Harris and Clark, 1996; Ledgard et al., 2001). The frequent grazing (8 rotations between April and October) implemented in this experiment resulted in relatively low pregrazing herbage mass, especially in the first 3 rotations, minimizing this shading effect. However, high herbage mass accumulation $(>2,000 \mathrm{~kg}$ of $\mathrm{DM} / \mathrm{ha})$ was necessary in the fourth and seventh rotations to ensure that the DMI and $\mathrm{CH}_{4}$ estimates could be undertaken in the base paddocks, which were directly comparable in terms of sward age and sown cultivars. The positive effect of low herbage mass accumulation during the spring on clover content has been previously reported (Holmes et al., 1992; Laidlaw et al., 1992; McKenzie et al., 2003b). Additionally, the tight grazing strategy (to approximately $4-\mathrm{cm}$ PostGSH) used in this experiment provided ideal conditions for light penetration to the base of the sward. Clover content in the GWc sward was relatively low compared with reports of other studies that used low ( $<100 \mathrm{~kg}$ of N/ha) N application (Bryant et al., 1982; Schils et al., 2000b; Humphreys et al., 2008). However, compared with studies that used a similar application of $\mathrm{N}$ fertilizer (Ledgard et al., 2001; McKenzie et al., 2003b; Humphreys et al., 2008), in the current study the clover content in the GWc sward was greater. The current experiment only evaluated the second year growth of the swards, so it is possible that the tight and frequent grazing management strategy used here could enhance sward clover content in subsequent grazing seasons. In a study with different $\mathrm{N}$ application rates, de Vliegher (2010) found an overall increase of 0.08 in clover content of mixed swards from the second to the third year of sward establishment.

In New Zealand, Harris and Clark (1996) found that GWc swards receiving either 200 or $400 \mathrm{~kg}$ of $\mathrm{N} / \mathrm{ha}$ produced 23 and $37 \%$ more herbage, respectively, than GWc swards receiving no N. Those authors concluded that relatively high sward clover content could be maintained at high $\mathrm{N}$ fertilizer application when frequent grazing is applied. In the current experiment, both swards had similar total herbage production and pregrazing herbage mass. It has been reported that a 
Table 4. Effect of sward type on sward measurements and herbage chemical composition, milk production, milk composition, BW and methane emissions of spring-calving dairy cows $(\mathrm{n}=40)$ during the September DMI estimation period (LSM)

\begin{tabular}{|c|c|c|c|c|}
\hline \multirow[b]{2}{*}{ Item } & \multicolumn{2}{|c|}{ Sward $^{1}$} & \multirow[b]{2}{*}{$\mathrm{SED}^{2}$} & \multirow[b]{2}{*}{$P$-value } \\
\hline & GO & GWc & & \\
\hline Pregrazing herbage mass $(>4 \mathrm{~cm}), \mathrm{kg}$ of $\mathrm{DM} / \mathrm{ha}$ & 1,950 & 1,990 & 97 & NS \\
\hline Sward density $(>4 \mathrm{~cm}), \mathrm{kg}$ of $\mathrm{DM} / \mathrm{cm}$ per hectare & 291 & 264 & 35.3 & NS \\
\hline Pregrazing herbage height, $\mathrm{cm}$ & 9.5 & 10.0 & 0.58 & NS \\
\hline Postgrazing herbage height, $\mathrm{cm}$ & 4.1 & 4.2 & 0.19 & NS \\
\hline DM & 190 & 168 & 17.6 & NS \\
\hline $\mathrm{OMD}^{3}$ & 780 & 789 & 10.9 & NS \\
\hline $\mathrm{CP}$ & 212 & 218 & 24.3 & NS \\
\hline $\mathrm{ADF}$ & 276 & 268 & 20.0 & NS \\
\hline $\mathrm{NDF}$ & 423 & 391 & 7.0 & $* *$ \\
\hline Ash & 119 & 108 & 13.6 & NS \\
\hline \multicolumn{5}{|l|}{ Animal measurement } \\
\hline $\mathrm{BW}, \mathrm{kg}$ & 535.1 & 512.9 & 15.40 & NS \\
\hline \multicolumn{5}{|l|}{$\mathrm{CH}_{4}$ emissions } \\
\hline $\mathrm{g} /$ cow per day & 360.5 & 353.6 & 19.27 & NS \\
\hline $\mathrm{g} / \mathrm{kg}$ of $\mathrm{DMI}$ & 24.5 & 21.5 & 1.17 & * \\
\hline $\mathrm{g} / \mathrm{kg}$ of milk & 26.5 & 26.0 & 1.58 & NS \\
\hline $\mathrm{g} / \mathrm{kg}$ of milk solids & 318.4 & 306.3 & 16.32 & NS \\
\hline $\mathrm{g} / \mathrm{kg}$ of milk fat & 593.9 & 558.4 & 30.32 & NS \\
\hline $\mathrm{g} / \mathrm{kg}$ of milk protein & 690.0 & 680.4 & 38.74 & NS \\
\hline $\mathrm{g} / \mathrm{kg}$ of $\mathrm{BW}$ & 0.67 & 0.69 & 0.032 & NS \\
\hline
\end{tabular}

${ }^{1} \mathrm{GO}=$ grass-only sward; GWc $=$ grass + white clover sward.

${ }^{2}$ Standard error of the difference.

${ }^{3} \mathrm{OMD}=\mathrm{OM}$ digestibility.

${ }^{*} P<0.01 ; * P<0.05$.

sward clover content of 0.30 is necessary to attain a balance between grass and clover components and maximize feed value in terms of quality and quantity (Harris and Thomas, 1973). Thus, the relatively low clover content measured in the GWc swards in the current experiment is the most likely reason for the absence of the synergistic effect in terms of herbage production. On the other hand, no negative effect was observed of clover on pregrazing herbage mass. Previous work (Leach et al., 2000; Schils et al., 2000b; Ribeiro Filho et al., 2003) has reported lower pregrazing herbage mass on GWc swards with high clover content values $(>0.29)$ compared with GO receiving $\mathrm{N}$ fertilizer; however, the difference between the treatments in those experiments might be related to the low $\mathrm{N}(<70 \mathrm{~kg}$ of $\mathrm{N} /$ ha per year) application that the GWc swards received.

Defoliation depth was similar for both treatments as a result of minimal differences in PreGSH and PostGSH. These responses in herbage utilization were expected, as the cows had a limited HA. However, a lower density was expected in the GWc swards due to the more accentuated differences in terms of lower content of struc- tural components present in clover compared with PRG (Ulyatt, 1970; Steg et al., 1994; Dewhurst et al., 2003).

\section{Herbage Chemical Composition}

In general terms, the herbage grown in both treatments was of high quality. Clover inclusion did not increase OMD compared with the herbage of the GO swards. This may have been due to the low clover content and the high $\mathrm{N}$ fertilizer application, which resulted in highly digestible herbage in both swards (Whitehead, 1995). Clover has higher digestibility than PRG (Ulyatt, 1970; Thomson, 1984), and at an inclusion rate of around 0.20 in GO swards, it would have been expected to enhance the overall herbage digestibility. Previous studies have shown that GWc swards have superior digestibility compared with GO swards (Leach et al., 2000; Schils et al., 2000b; Ribeiro Filho et al., 2003) at low $\mathrm{N}$ input levels. In contrast, previous experiments undertaken in Ireland have reported no differences in OMD in fertilized swards (up to $400 \mathrm{~kg}$ of $\mathrm{N} /$ ha) with low clover content compared with swards 
containing up to 0.24 clover content receiving low $\mathrm{N}$ input (90 kg of N/ha; Humphreys et al., 2008, 2009).

Previous work has shown that $\mathrm{N}$ fertilizer application to GWc swards increases pasture CP content and reduces NDF content (McKenzie et al., 2003a; Humphreys et al., 2009). Despite the high $\mathrm{N}$ fertilizer levels applied in the current experiment, the presence of clover tended to increase $\mathrm{CP}$ content by $4 \%$ and tended to decrease NDF content by $3 \%$ in the GWc herbage compared with the GO herbage. These effects were more evident from August onwards (except for CP in September; Table 2 ), when the sward clover content was high. Similarly, higher CP content values have been observed for GWc swards receiving no $\mathrm{N}$ fertilizer (Ribeiro Filho et al., $2003)$ or small amounts of $\mathrm{N}$ fertilizer $(70 \mathrm{~kg}$ of $\mathrm{N} /$ ha per year; Schils et al., 2000b) than for N-fertilized grass swards. Humphreys et al. (2009) found higher CP content in herbage samples from grass swards receiving $226 \mathrm{~kg}$ of $\mathrm{N} /$ ha per year than from GWc swards receiving $90 \mathrm{~kg}$ of $\mathrm{N} /$ ha per year. Lower NDF values for GWc swards compared with GO swards are commonly reported (Harris et al., 1998; Ribeiro Filho et al., 2003).

\section{Milk Production and Composition, BCS, and BW}

Similar to our findings, previous studies comparing milk production for the full season (Schils et al., 2000b; Humphreys et al., 2008) or for a short period of time (Phillips et al., 2000) did not find differences in milk yield between cows grazing either sward type. Some studies have reported lower milk yields (Leach et al., 2000; Ribeiro Filho et al., 2005) for cows grazing GWc swards compared with GO swards, whereas others reported opposite results (Harris et al., 1997; Phillips and James, 1998; Ribeiro Filho et al., 2003). The underlying factor in these different responses is that increased milk production from GWc swards compared with GO swards has been related to the increase in herbage DMI that the former promotes, rather than to the enhanced herbage quality generally attributed to GWc swards (Harris et al., 1997; Harris et al., 1998; Ribeiro Filho et al., 2003). Higher herbage DMI and milk yields are only possible when more herbage is offered to the GWc cows compared with the GO cows or where both groups have ad libitum herbage offer. In the current experiment, cows on both treatments had similar herbage intakes during the entire experiment as HA was restricted (to 16 and $17 \mathrm{~kg}$ of $\mathrm{DM} / \mathrm{cow}$ per day during the grazing season and during the herbage intake estimation periods, respectively) and cows depleted most of the herbage available.

The similar milk fat content observed throughout the entire season in this experiment is likely related to the low clover content of the GWc swards. Usually clover presence in the sward can decrease milk fat content (Thomson et al., 1985; Harris et al., 1997; Phillips and James, 1998) due to its faster rumen passage rate compared with grass (Beever et al., 1986; Steg et al., 1994). However, similar milk fat content from cows grazing GO and GWc swards with clover content between 0.22 and 0.42 has previously been reported (Leach et al., 2000; Phillips et al., 2000; Ribeiro Filho et al., 2005).

The similar milk protein content values observed for both treatments in this experiment can be attributed to the fact that both swards exceeded $\mathrm{CP}$ requirements for dairy cows (15 to 18\%; NRC, 2001; Pacheco and Waghorn, 2008) and is likely that this excess led to an underutilization of the $\mathrm{N}$ available in both systems, probably resulting in high $\mathrm{N}$ excretion (Ulyatt et al., 1988; van Dorland et al., 2007). Similar to our results, many grazing studies have found no effect of sward type on milk protein content (Phillips and James, 1998; Leach et al., 2000; Schils et al., 2000a).

Although no significant change occurred in BW between the start and end of the experiment for either treatment, the cows grazing GO swards were, on average, $19 \mathrm{~kg}$ heavier than those grazing GWc swards. It is unclear why this difference occurred. Other studies have found no effect of sward type on BW (Ribeiro Filho et al., 2003; Humphreys et al., 2008).

\section{Enteric Methane Emissions}

The per-cow $\mathrm{CH}_{4}$ emissions and the $\mathrm{CH}_{4}$ emissions per unit of feed intake estimated in this experiment are within the range of values reported for dairy cows offered comparable fresh forages (Ulyatt et al., 2002; Lee et al., 2004) and silages (van Dorland et al., 2007). The similar daily $\mathrm{CH}_{4}$ emissions between the 2 treatments contrast with previous indoor studies that found lower $\mathrm{CH}_{4}$ emission per cow when animals were offered GO compared with when cows were offered GWc mixtures with different clover contents ranging from 0.15 to 0.6 (Lee et al., 2004). However, the results agree with van Dorland et al. (2007), who reported no difference in percow $\mathrm{CH}_{4}$ emissions between cows fed GO and GWc (0.4 clover content) silages. Similar to our findings, previous studies have not found differences in the milk-related $\mathrm{CH}_{4}$ emission variables between similar fresh forages (Lee et al., 2004) or silage diets (van Dorland et al., 2007). In the current experiment, cows grazing GWc swards had slightly greater DMI than the GO cows, yet GWc cows produced $11.9 \%$ less $\mathrm{CH}_{4} / \mathrm{kg}$ of DMI $\left(\mathrm{CH}_{4}\right.$ yield) than the GO cows, which is greater than the $9.6 \%$ difference between sward types reported by Lee et al. (2004). Lee et al. (2004) found greater differences in $\mathrm{CH}_{4}$ per unit of feed intake between the 2 groups when the clover content of the GWc diet was increased. The 
lower $\mathrm{CH}_{4}$ emissions per unit of feed intake for the GWc cows compared with the GO cows can be attributed to 2 factors: (1) the digestibility characteristics that clover confer on the pasture and differences between clover and grass during the digestion process (clover has lower fiber content, higher in vitro digestibility, and faster rumen passage rate; Moe and Tyrrell, 1979; PinaresPatiño et al., 2003; Beauchemin et al., 2008), greater VFA content, and the lower ratio of acetic:propionic FA that the clover fermentation process produces compared with PRG (Beever et al., 1986; Purcell et al., 2012); and (2) the increased DMI (Moe and Tyrrell, 1979; Ulyatt et al., 2002; Pinares-Patino et al., 2009) that the legumes can promote when added to GO pasture. Effectively, the $\mathrm{CH}_{4}$ per unit of feed intake difference observed in this experiment was a product of the numerically lower $\mathrm{CH}_{4}$ emissions per cow and the tendency for greater DMI that the GWc cows had compared with the GO cows. The slight difference in DMI estimations observed between the groups might be related to differences in sward structure between the 2 sward types or discrepancies in the alkane content between the collected herbage samples and the actual grazed herbage. Both groups of cows were offered similar HA (4 cm above ground level) and had similar PostGSH; however, differences still could have existed in herbage availability. In the future, it would be recommended that all herbage measurements, both pre- and postgrazing, should be made to ground level. The importance of a representative sample of the actual grazed herbage in determining DMI through the $n$-alkane technique has been previously stated (Dove and Mayes, 1991; Dillon, 1993) and it is likely that the cows fed GWc selected for a greater clover content in their diet compared with that measured in the offered herbage (Rutter, 2006). The use of esophageal-fistulated animals might be more appropriate to overcome this issue, as a more representative sample of the actual herbage selected by cows while at grazing could be obtained. Seasonal variation in $\mathrm{CH}_{4}$ emissions of dairy cows has been reported previously (Ulyatt et al., 2002), with the highest values observed at peak lactation and then decreasing as lactation progressed. In the current experiment, $\mathrm{CH}_{4}$ emissions were only measured in late lactation (autumn), when the clover content was highest (0.24) and greater differences between species chemical composition and nutritional value was expected; hence, some caution is required in the overall interpretation of these results. Contrasting results found in the literature between GO and GWc, or even clover-only diets, denote that a more complex interaction of factors (secondary compounds, maturity, and environmental factors, among others) are involved in the $\mathrm{CH}_{4}$ emissions process and warrant further investigation.
Although $\mathrm{CH}_{4}$ yields from cows were slightly reduced by clover inclusion, it is likely that this benefit in terms of overall GHG emissions might be outweighed by the greater $\mathrm{N}_{2} \mathrm{O}$ emissions derived from the increased urinary $\mathrm{N}$ output that may occur due to the excess $\mathrm{CP}$ content of herbage. Additionally, the high $\mathrm{N}$ fertilizer application used might have further increased soil $\mathrm{N}$ emissions from the system (Ledgard et al., 1999).

\section{CONCLUSIONS}

The sward clover content attained in the GWc swards receiving high $\mathrm{N}$ fertilizer input and subjected to frequent and tight grazing was 0.20 . Contrary to our expectations, this rate of inclusion was not sufficient to improve GWc sward herbage production and quality compared with GO swards and so hypothesis 1 is rejected. However, the GWc sward had better quality than the GO sward in the last 3 rotations, when sward clover content was greatest. Similarly, hypothesis 2 is rejected, as no improvement in dairy cow productivity was observed. Although cows in late lactation had a tendency to consume more and emitted less $\mathrm{CH}_{4}$ per unit of feed intake when grazing GWc compared with GO swards, hypothesis (3) is rejected, as no difference existed in daily $\mathrm{CH}_{4}$ emissions or per unit of output, as no overall improvement was observed in milk yield or reduction in absolute $\mathrm{CH}_{4}$ emission. It is important to evaluate the long-term effect of frequent and tight grazing management of GWc swards receiving high $\mathrm{N}$ fertilizer input on the clover component and its effects on herbage and animal productivity.

\section{ACKNOWLEDGMENTS}

This research received funding from The Irish Dairy Levy Trust and from the European Community's Seventh Framework Programme (FP7/2007-2013) under the grant agreement no. FP7-244983 (MULTISWARD). The first author was a recipient of a Teagasc Walsh Fellowship (Moorepark, Fermoy, Co. Cork, Ireland). The authors acknowledge the advice received from Pat Dillon (Animal and Grassland Research and Innovation Centre, Teagasc, Moorepark, Fermoy, Co. Cork, Ireland) and Bob Mayes (The James Hutton Institute, Craigiebuckler, Aberdeen, UK) in regard to the DMI estimations using the $n$-alkane technique.

\section{REFERENCES}

Andrews, M., D. Scholefield, M. T. Abberton, B. A. McKenzie, S. Hodge, and J. A. Raven. 2007. Use of white clover as an alternative to nitrogen fertiliser for dairy pastures in nitrate vulnerable zones in the UK: Productivity, environmental impact and economic considerations. Ann. Appl. Biol. 151:11-23. 
AOAC (Association of Official Analytical Chemists). 1990. Official Methods of Analysis. Vol. 1. 15th ed. AOAC, Washington, DC.

Beauchemin, K. A., M. Kreuzer, F. O'Mara, and T. A. McAllister. 2008. Nutritional management for enteric methane abatement: A review. Aust. J. Exp. Agric. 48:21-27.

Beever, D. E., M. S. Dhanoa, H. R. Losada, R. T. Evans, S. B. Cammell, and J. France. 1986. The effect of forage species and stage of harvest on the processes of digestion occurring in the rumen of cattle. Br. J. Nutr. 56:439-454.

Bryant, A. M., K. A. MacDonald, and D. G. Clayton. 1982. Effects of nitrogen fertilizer on production of milk solids from grazed pasture. Pages 58-63 in Proc. Proc. N. Z. Grassl. Assoc. The New Zealand Grassland Association, Dunedin, New Zealand.

Buddle, B. M., M. Denis, G. T. Attwood, E. Altermann, P. H. Janssen, R. S. Ronimus, C. S. Pinares-Patiño, S. Muetzel, and D. Neil Wedlock. 2011. Strategies to reduce methane emissions from farmed ruminants grazing on pasture. Vet. J. 188:11-17.

Casey, J. W., and N. M. Holden. 2005. Analysis of greenhouse gas emissions from the average Irish milk production system. Agric. Syst. 86:97-114.

Cunningham, P. J., M. J. Blumenthal, M. W. Anderson, K. S. Prakash, and A. Leonforte. 1994. Perennial ryegrass improvement in Australia. N. Z. J. Agric. Res. 37:295-310.

Deighton, M. H., B. M. O'Loughlin, S. R. O. Williams, P. J. Moate, E. Kennedy, T. M. Boland, and R. J. Eckard. 2013. Declining sulphur hexafluoride permeability of polytetrafluoroethylene membranes causes overestimation of calculated ruminant methane emissions using the tracer technique. Anim. Feed Sci. Technol. 183:86-95.

de Vliegher, A. 2010. White clover effect on yield and quality of a Lolium perenne sward under cutting conditions. Pages 211-213 in Grassland Science in Europe, Volume 15. Mecke Druck und Verlag, Duderstadt, Germany.

Dewhurst, R. J., R. T. Evans, N. D. Scollan, J. M. Moorby, R. J. Merry, and R. J. Wilkins. 2003. Comparison of grass and legume silages for milk production. 2. In vivo and in sacco evaluations of rumen function. J. Dairy Sci. 86:2612-2621.

Dillon, P. 1993. The use of $n$-alkanes as markers to determine herbage intake, botanical composition of available or consumed herbage and in studies of digesta kinetics with dairy cows. Page 272. PhD Diss. National University of Ireland, Dublin, Ireland.

Dillon, P., J. R. Roche, L. Shalloo, and B. Horan. 2005. Optimising financial return from grazing in temperate pastures in temperate pastures. Pages 131-148 in Utilisation of grazed grass in temperate animal. Proc. satellite workshop of the XXth Int. Grassl. Congr. J. J. Murphy, ed. Wageningen Academic Publishers, Wageningen, the Netherlands.

Dove, H., and R. W. Mayes. 1991. The use of plant wax alkanes as marker substances in studies of the nutrition of herbivores-A review. Aust. J. Agric. Res. 42:913-952.

Eckard, R. J., C. Grainger, and C. A. M. de Klein. 2010. Options for the abatement of methane and nitrous oxide from ruminant production: A review. Livest. Sci. 130:47-56.

EEA (European Environment Agency). 2012. Annual European Union greenhouse gas inventory 1990-2010 and inventory report 2012 submission to the UNFCCC Secretariat. Page 1068. EEA, Copenhagen, Denmark.

Frame, J. 1991. Herbage production and quality of a range of secondary grass species at five rates of fertilizer nitrogen application. Grass Forage Sci. 46:139-151.

Frame, J., and A. G. Boyd. 1987. The effect of fertilizer nitrogen rate, white clover variety and closeness of cutting on herbage productivity from perennial ryegrass/white clover swards. Grass Forage Sci. $42: 85-96$.

Frame, J., and P. Newbould. 1986. Agronomy of white clover. Adv. Agron. 40:1-88

Gierus, M., J. Kleen, R. Loges, and F. Taube. 2012. Forage legume species determine the nutritional quality of binary mixtures with perennial ryegrass in the first production year. Anim. Feed Sci. Technol. 172:150-161.
Gilliland, T. J., D. McGilloway, and P. Conaghan. 2009. Influence of testing procedure on evaluation of white clover (Trifolium repens L.). Ir. J. Agric. Food Res. 48:227-242.

Harris, D. 1987. Population dynamics and competition. Pages 203-299 in White clover. M. J. Baker and W. M. Williams, ed. CAB International, Wallingford, UK.

Harris, S. L., M. J. Auldist, D. A. Clark, and E. B. L. Jansen. 1998. Effects of white clover content in the diet on herbage intake, milk production and milk composition of New Zealand dairy cows housed indoors. J. Dairy Res. 65:389-400.

Harris, S. L., and D. A. Clark. 1996. Effect of high rates of nitrogen fertiliser on white clover growth, morphology, and nitrogen fixation activity in grazed dairy pasture in northern New Zealand. N. Z. J. Agric. Res. 39:149-158.

Harris, S. L., D. A. Clark, M. J. Auldist, C. D. Waugh, and P. G. Laboyrie. 1997. Optimum white clover content for dairy pastures. Proc. N. Z. Grassl. Assoc. 59:29-33

Harris, W., and V. J. Thomas. 1973. Competition among pasture plants. 3. Effects of frequency and height of cutting on competition between white clover and two ryegrass cultivars. N. Z. J. Agric. Res. 16:49-59.

Holmes, C. W., C. J. Hoogendoorn, M. P. Ryan, and A. C. P. Chu. 1992. Some effects of herbage composition, as influenced by previous grazing management, on milk production by cows grazing on ryegrass/white clover pastures. 1. Milk production in early spring: Effects of different regrowth intervals during the preceding winter period. Grass Forage Sci. 47:309-315.

Humphreys, J., I. A. Casey, and A. S. Laidlaw. 2009. Comparison of milk production from clover-based and fertilizer-N-based grassland on a clay-loam soil under moist temperate climatic conditions. Ir. J. Agric. Food Res. 48:189-207.

Humphreys, J., K. O'Connell, and I. A. Casey. 2008. Nitrogen flows and balances in four grassland-based systems of dairy production on a clay-loam soil in a moist temperate climate. Grass Forage Sci. $63: 467-480$.

IPCC (Intergovernmental Panel on Climate Change). 2007. Climate Change 2007: The physical science basis. Contribution of working group I to the Fourth Assessment Report of the Intergovernmental Panel on Climate Change Page 52. S. Solomon, D. Qin, M. Manning, Z. Chen, M. Marquis, K. B. Averyt, M. Tignor, and H. L. Miller, ed. Cambridge University Press, Cambridge, UK, and New York, NY

Johnson, K., H. Westberg, J. Michal, and M. Cossalman. 2007. The $\mathrm{SF}_{6}$ tracer technique: Methane measurement from ruminants. Pages 33-67 in Measuring methane production from ruminants. H. P. S. Makkar and P. E. Vercoe, ed. Springer, Dordrecht, the Netherlands.

Kirwan, L., J. Connolly, J. Finn, C. Brophy, A. Lüscher, D. Nyfeler, and M. T. Sebastià. 2009. Diversity-interaction modeling: Estimating contributions of species identities and interactions to ecosystem function. Ecology 90:2032-2038.

Laidlaw, A. S., N. G. Teuber, and J. A. Withers. 1992. Out-of-season management of grass clover swards to manipulate clover content. Grass Forage Sci. 47:220-229.

Leach, K. A., J. A. Bax, D. J. Roberts, and C. Thomas. 2000. The establishment and performance of a dairy system based on perennial ryegrass - White clover swards compared with a system based on nitrogen fertilized grass. Biol. Agric. Hortic. 17:207-227.

Ledgard, S. F., J. W. Penno, and M. S. Sprosen. 1999. Nitrogen inputs and losses from clover/grass pastures grazed by dairy cows, as affected by nitrogen fertilizer application. J. Agric. Sci. 132:215225

Ledgard, S. F., M. S. Sprosen, J. W. Penno, and G. S. Rajendram. 2001. Nitrogen fixation by white clover in pastures grazed by dairy cows: Temporal variation and effects of nitrogen fertilization. Plant Soil 229:177-187.

Ledgard, S. F., M. S. Sprosen, K. W. Steele, and C. P. West. 1995. Productivity of white clover cultivars under intensive grazing, as affected by high nitrogen fertiliser application. N. Z. J. Agric. Res. 38:473-482. 
Lee, J. M., S. L. Woodward, G. C. Waghorn, and D. A. Clark. 2004. Methane emissions by dairy cows fed increasing proportions of white clover (Trifolium repens) in pasture. Pages 151-155 in Proc. Proc. N. Z. Grassl. Assoc. The New Zealand Grassland Association, Dunedin, New Zealand.

Lowman, B. G., N. A. Scott, and S. H. Somerville. 1976. Condition scoring of cattle. Vol. 6. Bulletin. School of Agriculture, Edinburgh, UK.

Mayes, R. W., C. S. Lamb, and P. M. Colgrove. 1986. The use of dosed and herbage n-alkanes as markers for the determination of herbage intake. J. Agric. Sci. 107:161-170.

McKenzie, F. R., J. L. Jacobs, and G. Kearney. 2003a. Long-term effects of multiple applications of nitrogen fertiliser on grazed dryland perennial ryegrass/white clover dairy pastures in south-west Victoria. 3. Botanical composition, nutritive characteristics, mineral content, and nutrient selection. Aust. J. Agric. Res. 54:477485 .

McKenzie, F. R., J. L. Jacobs, P. Riffkin, G. Kearney, and M. McCaskill. 2003b. Long-term effects of multiple applications of nitrogen fertiliser on grazed dryland perennial ryegrass/white clover dairy pastures in south-west Victoria. 1. Nitrogen fixation by white clover. Aust. J. Agric. Res. 54:461-469.

Moe, P. W., and H. F. Tyrrell. 1979. Methane production in dairy cows. J. Dairy Sci. 62:1583-1586.

NRC. 2001. Nutrient Requirements of Dairy Cattle. National Academies Press, Washington, DC.

Pacheco, D., and G. Waghorn. 2008. Dietary nitrogen-Definitions, digestion, excretion and consequences of excess for grazing ruminants. Pages 107-116 in Proc. Proc. N. Z. Grassl. Assoc. The New Zealand Grassland Association, Dunedin, New Zealand.

Phelan, P., I. A. Casey, and J. Humphreys. 2013. The effect of target postgrazing height on sward clover content, herbage yield, and dairy production from grass-white clover pasture. J. Dairy Sci. 96:1598-1611.

Phillips, C. 1998. The use of individual dairy cows as replicates in the statistical analysis of their behaviour at pasture. Appl. Anim. Behav. Sci. 60:365-369.

Phillips, C. J. C., and N. L. James. 1998. The effects of including white clover in perennial ryegrass swards and the height of mixed swards on the milk production, sward selection and ingestive behaviour of dairy cows. Anim. Sci. 67:195-202.

Phillips, C. J. C., N. L. James, and H. M. Nyallu. 2000. The effects of forage supplements on the ingestive behaviour and production of dairy cows grazing ryegrass only or mixed ryegrass and white clover pastures. Anim. Sci. 70:555-559.

Pinares-Patiño, C. S., M. J. Ulyatt, K. R. Lassey, T. N. Barry, and C. W. Holmes. 2003. Rumen function and digestion parameters associated with differences between sheep in methane emissions when fed chaffed lucerne hay. J. Agric. Sci. 140:205-214.

Pinares-Patino, C. S., G. C. Waghorn, R. S. Hegarty, and S. O. Hoskin. 2009. Effects of intensification of pastoral farming on greenhouse gas emissions in New Zealand. N. Z. Vet. J. 57:252-261.

Purcell, P. J., J. Grant, T. M. Boland, D. Grogan, and P. O'Kiely. 2012. The in vitro rumen methane output of perennial grass species and white clover varieties, and associative effects for their binary mixtures, evaluated using a batch-culture technique. Anim. Prod. Sci. 52:1077-1088.

Ribeiro Filho, H. M. N., R. Delagarde, and J. L. Peyraud. 2003. Inclusion of white clover in strip-grazed perennial ryegrass swards: Herbage intake and milk yield of dairy cows at different ages of sward regrowth. Anim. Sci. 77:499-510.

Ribeiro Filho, H. M. N., R. Delagarde, and J. L. Peyraud. 2005. Herbage intake and milk yield of dairy cows grazing perennial ryegrass swards or white clover/perennial ryegrass swards at low- and medium-herbage allowances. Anim. Feed Sci. Technol. 119:13-27.

Rook, A. J., and C. A. Huckle. 1995. Synchronization of ingestive behaviour by grazing dairy cows. Anim. Sci. 60:25-30.

Rutter, S. M. 2006. Diet preference for grass and legumes in freeranging domestic sheep and cattle: Current theory and future application. Appl. Anim. Behav. Sci. 97:17-35.
SAS Institute. 2003. SAS User's Guide: Statistics. SAS Institute Inc. Cary, NC.

Schils, R. L. M., T. J. Boxem, C. J. Jagtenberg, and M. C. Verboon. 2000a. The performance of a white clover based dairy system in comparison with a grass/fertiliser-N system. II. Animal production, economics and environment. Neth. J. Agric. Sci. 48:305-318.

Schils, R. L. M., T. J. Boxem, K. Sikkema, and G. André. 2000b. The performance of a white clover based dairy system in comparison with a grass/fertiliser-N system. I. Botanical composition and sward utilisation. Neth. J. Agric. Sci. 48:291-303.

Steen, R. W. J., and A. S. Laidlaw. 1995. The effect of fertiliser nitrogen input on the stock-carrying capacity of ryegrass/white clover swards continuously grazed by beef cattle. Ir. J. Agric. Food Res. $34: 123-132$.

Steg, A., W. M. van Straalen, V. A. Hindle, W. A. Wensink, F. M. H. Dooper, and R. L. M. Schils. 1994. Rumen degradation and intestinal digestion of grass and clover at two maturity levels during the season in dairy cows. Grass Forage Sci. 49:378-390.

Thompson, L. 1993. The influence of the radiation environment around the node on morphogenesis and growth of white clover (Trifolium repens). Grass Forage Sci. 48:271-278.

Thomson, D. J. 1984. The nutritive value of white clover. Pages 78-92 in Forage Legumes. Proc. Occasional Symposium of the British Grassland Society. Vol. 16. D. J. Thomson, ed. Leverpress, Ipswich, UK.

Thomson, D. J., D. E. Beever, M. J. Haines, S. B. Cammell, R. T. Evans, M. S. Dhanoa, and A. R. Austin. 1985. Yield and composition of milk from Friesian cows grazing either perennial ryegrass or white clover in early lactation. J. Dairy Res. 52:17-31.

Tilley, J. M. A., and R. A. Terry. 1963. A two-stage technique for the in vitro digestion of forage crops. Grass Forage Sci. 18:104-111.

Ulyatt, M. J., D. J. Thomson, D. E. Beever, R. T. Evans, and M. J. Haines. 1988. The digestion of perennial ryegrass (Lolium perenne $\mathrm{cv}$. Melle) and white clover (Trifolium repens $\mathrm{cv}$. Blanca) by grazing cattle. Br. J. Nutr. 60:137-149.

Ulyatt, M. J. 1970. Evaluation of pasture quality under New Zealand conditions. Proc. N. Z. Grassl. Assoc. 32:61-68.

Ulyatt, M. J., K. R. Lassey, I. D. Shelton, and C. F. Walker. 2002. Seasonal variation in methane emission from dairy cows and breeding ewes grazing ryegrass/white clover pasture in New Zealand. N. Z. J. Agric. Res. 45:217-226.

UNFCCC (United Nations Framework Convention on Climate Change). 1997. Kyoto Protocol to the United Nations Framework Convention on Climate Change. UNFCCC, Kyoto, Japan.

van Dorland, H. A., H.-R. Wettstein, H. Leuenberger, and M. Kreuzer. 2007. Effect of supplementation of fresh and ensiled clovers to ryegrass on nitrogen loss and methane emission of dairy cows. Livest. Sci. 111:57-69.

Van Soest, P. J., J. B. Robertson, and B. A. Lewis. 1991. Methods for dietary fiber, neutral detergent fiber, and nonstarch polysaccharides in relation to animal nutrition. J. Dairy Sci. 74:3583-3597.

Waghorn, G. C., S. L. Woodward, M. Tavendale, and D. A. Clark. 2006 Inconsistencies in rumen methane production-Effects of forage composition and animal genotype. Int. Congr. Ser. 1293:115-118.

Whitehead, D. C. 1995. Grassland Nitrogen. CAB International, Wallingford, UK.

Williams, S. R. O., P. J. Moate, M. C. Hannah, B. E. Ribaux, W. J. Wales, and R. J. Eckard. 2011. Background matters with the $\mathrm{SF}_{6}$ tracer method for estimating enteric methane emissions from dairy cows: A critical evaluation of the $\mathrm{SF}_{6}$ procedure. Anim. Feed Sci. Technol. 170:265-276.

Wilman, D., and G. H. P. Acuña. 1993. Effects of cutting height on the growth of leaves and stolons in perennial ryegrass-white clover swards. J. Agric. Sci. 121:39-46.

Yu, Y.-W., Z. B. Nan, and C. Matthew. 2008. Population relationships of perennial ryegrass and white clover mixtures under differing grazing intensities. Agric. Ecosyst. Environ. 124:40-50.

Zimmerman, P. R., inventor. 1993. System for measuring metabolic gas emissions from animals. US Patent and Trademark Office, assignee. US Patent No. 5, 265,618. 